\title{
Systematic review and meta-analysis of long-term outcomes in adults undergoing the Ross procedure
}

\author{
Campbell D. Flynn ${ }^{1}$, Joshua H. De Bono" ${ }^{1 \#}$, Benjamin Muston ${ }^{2,3 \#}$, Nivedita Rattan ${ }^{4 \#}$, David H. Tian ${ }^{5}$, \\ Marco Larobina ${ }^{1,6,7}$, Michael O'Keefe ${ }^{1,7}$, Peter Skillington ${ }^{1,6,7}$ \\ ${ }^{1}$ Department of Cardiothoracic Surgery, Epworth Hospital, Richmond, Victoria, Australia; ${ }^{2}$ Collaborative Research Group, Sydney, Australia; \\ ${ }^{3}$ Faculty of Medicine, University of New South Wales, Sydney, Australia; ${ }^{4}$ Royal Prince Alfred Hospital, Camperdown, NSW, Australia; ${ }^{5}$ Department \\ of Anaesthesia and Perioperative Medicine, Westmead Hospital, Sydney, Australia; ${ }^{6}$ University of Melbourne, Melbourne, Victoria, Australia; \\ ${ }^{7}$ Department of Cardiothoracic Surgery and Cardiology, Royal Melbourne Hospital, Melbourne, Victoria, Australia \\ \#These three authors contributed equally to the preparation of this systematic review. \\ Correspondence to: Dr. Campbell D. Flynn. Department of Cardiothoracic Surgery, Epworth Hospital, Richmond, Victoria, Australia. \\ Email: campbellf@doctors.org.uk.
}

Background: The management of aortic valve disease is becoming increasingly complicated with the evolution of treatment options available to cardiac surgeons and cardiologist. Pulmonary autograft replacement of the aortic valve, commonly known as the Ross procedure, involves excision of the pulmonary valve from the right ventricular outflow tract and implantation in the aortic position. This systematic review aims to evaluate the long-term outcomes, following the Ross procedure.

Methods: An electronic search strategy queried five online medical referencing databases from inception to 21 August 2020. All studies detailing the long-term outcomes of adults undergoing the Ross procedure were included. A random effects model was used to determine pooled continuous data. Enhanced secondary survival analysis was performed on reconstructed individual patient data.

Results: Twenty-three studies were included in the qualitative synthesis, including a total of 6,278 patients with a mean follow-up duration of $6.0 \pm 2.8$ years. Long-term survival was $95.6 \%, 91.8 \%, 86.3 \%$ and $80.5 \%$ at five, ten, fifteen and twenty years, respectively. Freedom from autograft reoperation was 95.7\%, 91.2\%, $84.9 \%$ and $76.1 \%$ at five, ten, fifteen and twenty years, respectively.

Conclusions: When performed in experienced centres and for appropriately selected patients, the Ross procedure represents a durable replacement of the aortic valve with excellent long-term survival.

Keywords: Ross procedure; pulmonary autograft; aortic valve surgery; aortic valve replacement

Submitted May 06, 2021. Accepted for publication Jun 18, 2021.

doi: 10.21037/acs-2021-rp-30

View this article at: https://dx.doi.org/10.21037/acs-2021-rp-30

\section{Introduction}

The management of aortic valve disease is becoming increasingly complicated with the evolution of treatment options available to cardiac surgeons and cardiologists. The question of which operation is optimal for younger patients is particularly pertinent. A young patient will almost certainly have a life expectancy greater than the projected functional lifespan of a bioprosthetic valve replacement, whereas a mechanical prosthesis necessitates life-long anticoagulation and, is associated with an increased risk of thromboembolism and bleeding events $(1,2)$.

Pulmonary autograft replacement of the aortic valve, or the Ross procedure, was developed in 1967 (3), whereby the pulmonary valve was excised from the right ventricular outflow tract (RVOT) and implanted in the aortic position using a subcoronary implantation technique. The RVOT is reconstructed using a pulmonary valve homograft. This operation aims to replace the aortic valve with autologous tissue, obviating the need for anticoagulation and should 
have long-term durability with physiological hemodynamic function. Since its inception, various techniques of performing the Ross procedure have evolved including autograft free-standing root replacement, which may be supported or unsupported in addition to the originally described subcoronary technique. In general, preference has been to use a homograft to reconstruct the RVOT, however, there is some experience using xenograft where there is no access to cryopreserved homograft.

Nonetheless, this operation is very technically demanding, involving a significant learning curve with a risk of early failure and the need for reoperation $(4,5)$. Furthermore, operating on both the aortic and pulmonary valves introduces the risk of complications at both sites. Autograft failure can occur due to leaflet degeneration, annular or neo-aortic dilatation. Homograft failure can occur due to pulmonary regurgitation or more commonly, pulmonary artery stenosis.

In this systematic review we aim to determine the long-term outcomes of the Ross procedure performed in experienced centers in adults.

\section{Methods}

\section{Literature search strategy}

This meta-analysis was performed in accordance with the Preferred Reporting Items for Systematic Reviews and Meta-Analyses (PRISMA) recommendations and guidelines. The search strategy queried the electronic databases EMBASE, Ovid Medline, the entire Cochrane Central Register of Controlled Trails (CCRCT), Cochrane Database of Systematic Reviews (CDSR) and the Database of Abstracts of Reviews of Effects (DARE) from inception to 21 August 2020. The search terms were: Ross procedure OR aortic autograft OR pulmonary autograft OR pulmonic autograft OR aortic valve autograft OR pulmonary valve autograft OR pulmonic valve autograft. The reference lists of previous systematic reviews were assessed to ensure no additional publications were missed.

\section{Search criteria}

Eligibility for inclusion in this systematic review and metaanalysis included all studies that assessed the outcomes of adult patients undergoing treatment for aortic valve disease with the Ross procedure. In order to ensure sufficient center experience, papers were only included if more than thirty cases were reported. To ensure adequate follow-up duration was observed, only papers that detailed a minimum mean follow-up of five years were included. Only English language papers were analyzed. Studies with inadequate data regarding outcomes and studies in which we were unable to separate pediatric from adult populations were excluded. For the purpose of this study, patients aged sixteen years and older, are classified as an adult. If centers reported outcomes of overlapping patient series, the most complete, contemporary series was analyzed. Conference abstracts, case reports, editorials, reviews, letters and expert opinion pieces were excluded. Article identification and inclusion were performed independently by two authors (CD Flynn and JH De Bono) and discussed until consensus was reached.

\section{Data extraction}

For the assessed papers, data was extracted from the reviewed text, tables and figures. Data was extracted independently by two authors (B Muston and N Rattan), then checked and validated by a senior author (CD Flynn), with any discrepancies reviewed and discussed until consensus was reached. The recorded parameters included: operative technique used for autograft, RVOT reconstruction technique, patient demographics, early mortality (in hospital or within the first thirty days postoperatively), stroke and reoperation information (excluding emergency reoperation for tamponade, bleeding or low cardiac output state).

A priori subgroup assessments were to be performed on long-term reoperation rates determined by operative technique of autograft replacement and RVOT reconstruction strategy.

\section{Statistical analysis}

Meta-analysis of operative and post-operative variables was performed. Incidence data was assessed using Comprehensive Meta-analysis v3.3 (Biostat, Englewood, NJ, USA). For continuous data with central tendency described using median values, the mean and standard deviation were estimated using calculations described by Wan and colleagues (6). Due to the varied patient populations, a random-effects model was chosen for all analyses. Data significance and heterogeneity were assessed using the Cochrane Q statistic and the $\mathrm{I}^{2}$ test statistic respectively, with significance set at $\mathrm{P}$ value $<0.05$ and significant heterogeneity denoted by an $\mathrm{I}^{2}$ value $>50$. Guyot's iterative algorithm was applied to digitized KaplanMeier curves to reconstruct individual patient data $(7,8)$. 
This approach assumed a constant, non-informative censoring mechanism. The reconstructed patient data were then aggregated to form the combined survival curve. A log-rank test was not used to assess the significance of comparison between survival curves due to an increased level of assumption in the reconstruction. Digitization of source Kaplan Meier curves was performed using DigitizeIt (version 2.5.9, Braunschweig, Germany). Survival analysis was performed using $\mathrm{R}$ ( $\mathrm{R}$ version 3.6.1, R Foundation for Statistical Computing, Vienna, Austria).

\section{Study quality}

Study quality was assessed using the modified Canadian National Institute of Health Economics (CNIHE) assessment tool for case series (9) (Table S1). Studies were considered high quality if they addressed at least thirteen of the fifteen criteria outlined in the CNIHE tool, of moderate quality if ten to twelve criteria were addressed and of low quality if fewer than ten criteria were addressed (Table S2). Study quality was independently assessed by two investigators (B Muston and N Rattan) with review and consensus achieved with a senior author (CD Flynn).

\section{Results}

\section{Search results}

The search strategy revealed 2,051 citations after duplicates were removed that underwent title and abstract review. No additional references were identified on review of reference lists. After initial review, 297 full text articles were reviewed and twenty-three papers were identified that fulfilled the pre-defined inclusion and exclusion criteria (see PRISMA flow chart, Figure S1).

\section{Study quality}

Study quality was variable; four studies were deemed high quality, thirteen studies were deemed moderate quality, with the remaining six studies being low quality (Figure S1). Deficiencies in study quality tended to be due to the retrospective, single center study design, failure to detail losses to follow-up and poor reporting of conflicts of interest.

\section{Patient demographic results}

The total patient population consisted of 6,278 individual patients with a mean follow-up duration of 9.8 years [95\% confidence interval (CI): 8.5-11.1 years, $\mathrm{I}^{2}=99 \%$ ] (Table 1). The mean age of the patient population was 38.7 years (95\% CI: $38.5-38.8$ years, $\mathrm{I}^{2}=100 \%$ ). The most commonly performed technique to replace the aortic valve with autograft was an unsupported free-standing aortic root replacement, which was performed in 3,130 patients (49.9\% of patients). A supported aortic root replacement was used for 1,629 patients (25.9\% of patients) with support being afforded by either autologous aortic tissue or prosthetic tissue. A subcoronary technique was used in 1,280 patients (20.4\% of patients). The technique of implanting the autograft was undefined for 239 patients (3.4\% of patients). Two papers included information for pediatric patient populations but sufficient data was available to differentiate the majority of the adult patient populations; for the paper by Oeser and colleagues (10) patients over the age of eighteen were able to be included and the paper by Bansal and colleagues (11), patients over the age of twenty were able to be included.

The RVOT was reconstructed using cryopreserved or fresh decellularized pulmonary homograft in 4,909 (78.2\% of patients) patients and xenograft or other prosthetic material was used for 1,356 patients ( $21.6 \%$ of patients). The method of addressing the RVOT was unknown in thirteen patients $(0.2 \%$ of patients).

\section{Clinical outcomes}

Early mortality data was able to be extracted from twentytwo of the twenty-three studies (11-32). Overall, there were 105 early deaths in 6,059 patients $(1.73 \%)$ within thirty days of the initial operation. Data on stroke during the follow-up period was reported in thirteen studies (11-17,21,23,24,26,30,32). There were forty-six strokes reported $(1.5 \%)$ in a patient population of 3,019 patients during the follow-up period. Ross related reoperation data was reported in twenty studies (11-16,18,20-32). There were 531 Ross related reoperations $(10.26 \%)$ in a population of 5,175 patients during the entire follow-up period. Indication for Ross related reoperation during the entire follow-up period was reliably reported in fourteen studies $(12,13,16,18,22-26,28-32)$ with a total patient population of 3,700 patients. Reoperation was required on the autograft for 227 patients $(5.98 \%)$, RVOT reconstruction in 120 patients $(3.24 \%)$ and both the autograft and RVOT reconstruction in fifty-four patients $(1.46 \%)$.

Subsequent endocarditis was reported in fourteen studies 


\begin{tabular}{|c|c|c|c|c|c|c|c|c|c|c|c|c|c|c|c|c|}
\hline First & Year & Location & Study design & $\begin{array}{l}\text { Study } \\
\text { focus }\end{array}$ & $\begin{array}{l}\text { Number } \\
\text { of patients } \\
\text { overall }\end{array}$ & $\begin{array}{l}\text { Number of } \\
\text { subcoronary } \\
\text { autograft }\end{array}$ & $\begin{array}{l}\begin{array}{l}\text { Number of } \\
\text { unsupported root } \\
\text { replacement }\end{array} \\
\end{array}$ & $\begin{array}{l}\text { Number of } \\
\text { supported root } \\
\text { replacement }\end{array}$ & $\begin{array}{l}\text { No pulmonary } \\
\text { homograft for } \\
\text { RVOT }\end{array}$ & $\begin{array}{l}\text { No } \\
\text { xenograft for } \\
\text { RVOT }\end{array}$ & $\begin{array}{l}\text { Follow-up } \\
\text { overall } \\
\text { (years) }\end{array}$ & $\begin{array}{l}\text { Mean age } \\
\text { overall (years) }\end{array}$ & $\begin{array}{l}\text { Number of Ross } \\
\text { related-redo } \\
\text { surgery overall }\end{array}$ & $\begin{array}{l}\text { Number of } \\
\text { redo- } \\
\text { autograft }\end{array}$ & $\begin{array}{l}\text { Number of } \\
\text { redo-homograft } \\
\text { (RVOT) }\end{array}$ & $\begin{array}{l}\text { Number of redo- } \\
\text { combined autograft } \\
+ \text { homograft }\end{array}$ \\
\hline Aljassim ${ }^{a}$ & 2020 & $\begin{array}{l}\text { Riyadh, } \\
\text { Saudi Arabia }\end{array}$ & $\begin{array}{l}\text { Retrospective single } \\
\text { centre }\end{array}$ & $\begin{array}{l}\text { Single institution experience of Ross } \\
\text { procedure }\end{array}$ & 216 & - & 216 & - & 216 & 0 & $16.7 \pm 3.7$ & $26.3 \pm 8.2$ & 50 & 17 & 21 & 12 \\
\hline Loobuyck & 2020 & Lille, France & $\begin{array}{l}\text { Retrospective single } \\
\text { centre }\end{array}$ & $\begin{array}{l}\text { Ross procedure for } \\
\text { endocarditis in adults }\end{array}$ & 38 & 3 & 30 & 5 & 21 & 17 & $10 \pm 11.2$ & $33.9 \pm 8.1$ & 8 & 4 & 3 & 1 \\
\hline Chauvette & 2020 & $\begin{array}{l}\text { Montreal, } \\
\text { Canada }\end{array}$ & $\begin{array}{l}\text { Retrospective, } \\
\text { multicentre }\end{array}$ & $\begin{array}{l}\text { Ross procedure for } \\
\text { endocarditis in adults }\end{array}$ & 31 & - & 31 & - & 21 & 10 & - & $43 \pm 12$ & 0 & - & - & - \\
\hline Sharifulin & 2019 & $\begin{array}{l}\text { Novosibirsk, } \\
\text { Russia }\end{array}$ & $\begin{array}{l}\text { Retrospective single } \\
\text { centre }\end{array}$ & $\begin{array}{l}\text { Long-term pulmonary valve function } \\
\text { after Ross in adults }\end{array}$ & 793 & - & 773 & 20 & 185 & 608 & $6.5 \pm 3.2$ & $46.5 \pm 12.4$ & 62 & - & - & - \\
\hline Oeser ${ }^{b}$ & 2019 & Vienna, Austria & $\begin{array}{l}\text { Retrospective single } \\
\text { centre }\end{array}$ & $\begin{array}{l}\text { Long-term pulmonary valve function } \\
\text { atter Rosss } \\
\text { in adults }\end{array}$ & 219 & - & - & - & 219 & 0 & $12.9 \pm 7$ & $37.1 \pm 5.4$ & - & - & - & - \\
\hline Guerreiro & 2019 & $\begin{array}{l}\text { Carnaxide, } \\
\text { Portugal }\end{array}$ & $\begin{array}{l}\text { Retrospective single } \\
\text { centre }\end{array}$ & $\begin{array}{l}\text { Single institution experience of } \\
\text { Ross procedure }\end{array}$ & 56 & 48 & 8 & 0 & 56 & 0 & $20.7 \pm 3$ & $44 \pm 12$ & 11 & 10 & 1 & 0 \\
\hline Christ & 2019 & $\begin{array}{l}\text { Berlin, } \\
\text { Germany }\end{array}$ & $\begin{array}{l}\text { Prospective, single } \\
\text { centre }\end{array}$ & $\begin{array}{l}\text { Ross procedures } \\
\text { performed reairing RVOT with } \\
\text { decellularized graft }\end{array}$ & 492 & 370 & 5 & 116 & 0 & 492 & $7.7 \pm 4.3$ & $57.2 \pm 10.6$ & - & - & - & - \\
\hline Etnel & 2018 & $\begin{array}{l}\text { Parana, } \\
\text { Brazil }\end{array}$ & $\begin{array}{l}\text { Retrospective single } \\
\text { centre }\end{array}$ & $\begin{array}{l}\text { Propensity matched } \\
\text { comparison of DA and SCA }\end{array}$ & 260 & - & 220 & 32 & 260 & 0 & $8.7 \pm 3.6$ & $22.1 \pm 8.3$ & 23 & 14 & 6 & 3 \\
\hline Buratto & 2018 & $\begin{array}{l}\text { Melbourne, } \\
\text { Aus }\end{array}$ & $\begin{array}{l}\text { Retrospective single } \\
\text { centre }\end{array}$ & $\begin{array}{l}\text { Comparison between ross procedure } \\
\text { and mechanical AVR }\end{array}$ & 392 & 0 & 0 & 381 & 392 & 0 & $10 \pm 7$ & $39 \pm 13$ & - & - & - & - \\
\hline $\begin{array}{l}\text { Pardo } \\
\text { González }\end{array}$ & 2017 & $\begin{array}{l}\text { Cordoba, } \\
\text { Spain }\end{array}$ & $\begin{array}{l}\text { Prospective, single } \\
\text { centre }\end{array}$ & $\begin{array}{l}\text { Long-term pulmonary } \\
\text { homograft function after Ross } \\
\text { procedure patients }\end{array}$ & 86 & 0 & 86 & 0 & 86 & 0 & $10.7 \pm 3.8$ & $34 \pm 9$ & 21 & - & - & - \\
\hline Sievers & 2016 & $\begin{array}{l}\text { Lubeck, } \\
\text { Germany }\end{array}$ & $\begin{array}{l}\text { Prospective, } \\
\text { multicentre }\end{array}$ & $\begin{array}{l}\text { Update of German Ross } \\
\text { registry data }\end{array}$ & 1779 & 823 & 249 & 707 & 1,617 & 149 & $8.3 \pm 5.1$ & $44.7 \pm 11.6$ & 175 & 84 & 69 & 22 \\
\hline Mazine & 2016 & $\begin{array}{l}\text { Toronto, } \\
\text { Canada }\end{array}$ & $\begin{array}{l}\text { Retrospective single } \\
\text { centre }\end{array}$ & $\begin{array}{l}\text { Propensity matched study comparing } \\
\text { mechanical AVR and Ross }\end{array}$ & 208 & - & 104 & 104 & 208 & 0 & $14.2 \pm .6 .5$ & $37.2 \pm 10.2$ & 17 & 10 & 4 & 3 \\
\hline Mastrobuoni & 2016 & $\begin{array}{l}\text { Brussels, } \\
\text { Belgium }\end{array}$ & $\begin{array}{l}\text { Retrospective single } \\
\text { centre }\end{array}$ & $\begin{array}{l}\text { Single institution experience of Ross } \\
\text { procedure }\end{array}$ & 306 & 7 & 168 & 131 & 288 & 18 & $9.9 \pm 7.8$ & $41.7 \pm 9.7$ & 39 & 28 & 3 & 8 \\
\hline Juthier & 2015 & Lille, France & $\begin{array}{l}\text { Retrospective single } \\
\text { centre }\end{array}$ & $\begin{array}{l}\text { Outcome of stentless porcine } \\
\text { pulmonary valves in Ross procedures }\end{array}$ & 61 & 11 & 45 & 5 & 0 & 61 & $5.7 \pm 3.2$ & $38 \pm 7.6$ & 6 & 6 & 0 & 0 \\
\hline Escarain & 2015 & $\begin{array}{l}\text { Buenos Aires, } \\
\text { Argentina }\end{array}$ & $\begin{array}{l}\text { Retrospective single } \\
\text { centre }\end{array}$ & $\begin{array}{l}\text { Single institution experience of Ross } \\
\text { procedure }\end{array}$ & 263 & 0 & 263 & 0 & 263 & 0 & $7.5 \pm 5$ & $42 \pm 14$ & 14 & 10 & 1 & 3 \\
\hline Bansal $\left.\right|^{\circ}$ & 2015 & $\begin{array}{l}\text { Los Angeles, } \\
\text { California }\end{array}$ & $\begin{array}{l}\text { Retrospective single } \\
\text { centre }\end{array}$ & $\begin{array}{l}\text { Age-related outcomes of ross } \\
\text { procedures }\end{array}$ & 95 & - & - & 95 & 95 & 0 & $6.1 \pm 3.4$ & $38 \pm 0.8$ & 3 & - & - & - \\
\hline Ryan & 2011 & Dallas, Texas & $\begin{array}{l}\text { Prospective, single } \\
\text { centre }\end{array}$ & $\begin{array}{l}\text { Single institution experience of Ross } \\
\text { procedure }\end{array}$ & 160 & - & 160 & - & 160 & 0 & $5.4 \pm 3.1$ & $42 \pm 11.1$ & 15 & 15 & - & - \\
\hline Brown & 2011 & $\begin{array}{l}\text { Indianapolis, } \\
\text { Indiana }\end{array}$ & $\begin{array}{l}\text { Retrospective single } \\
\text { centre }\end{array}$ & $\begin{array}{l}\text { Single institution experience of Ross } \\
\text { procedure }\end{array}$ & 101 & - & 101 & - & 101 & 0 & $6 \pm 3.9$ & $36 \pm 12.3$ & 9 & 7 & 1 & 1 \\
\hline Pergola & 2020 & $\begin{array}{l}\text { Gothenburg, } \\
\text { Sweden }\end{array}$ & $\begin{array}{l}\text { Retrospective single } \\
\text { centre }\end{array}$ & $\begin{array}{l}\text { Single institution experience of Ross } \\
\text { procedure }\end{array}$ & 91 & - & 91 & - & 91 & 0 & $8.1 \pm 2.3$ & $45 \pm 12$ & 12 & 9 & 3 & 0 \\
\hline El-Hamamsy & 2010 & $\begin{array}{l}\text { London, } \\
\text { England }\end{array}$ & $\begin{array}{l}\text { Prospective, single } \\
\text { centre }\end{array}$ & $\begin{array}{l}\mathrm{RCT} \text { comparing Ross and homograft } \\
\text { root replacement }\end{array}$ & 108 & - & 108 & - & 108 & 0 & $10.2 \pm 3.2$ & $41 \pm 35.3$ & 8 & 1 & 7 & 0 \\
\hline Frigiola & 2008 & Milan, Italy & $\begin{array}{l}\text { Retrospective single } \\
\text { centre }\end{array}$ & $\begin{array}{l}\text { Single institution experience of Ross } \\
\text { procedure }\end{array}$ & 110 & - & 110 & - & 110 & 0 & $6.8 \pm 2.5$ & $30.2 \pm 10.5$ & 8 & 7 & 0 & 1 \\
\hline Settepani & 2005 & $\begin{array}{l}\text { Nieuwegein, } \\
\text { The } \\
\text { Netherlands }\end{array}$ & $\begin{array}{l}\text { Retrospective single } \\
\text { centre }\end{array}$ & $\begin{array}{l}\text { Single institution experience of Ross } \\
\text { procedure }\end{array}$ & 103 & - & 103 & - & 102 & 1 & $6 \pm 2.8$ & $35.2 \pm 9.5$ & 6 & 5 & 1 & 0 \\
\hline
\end{tabular}




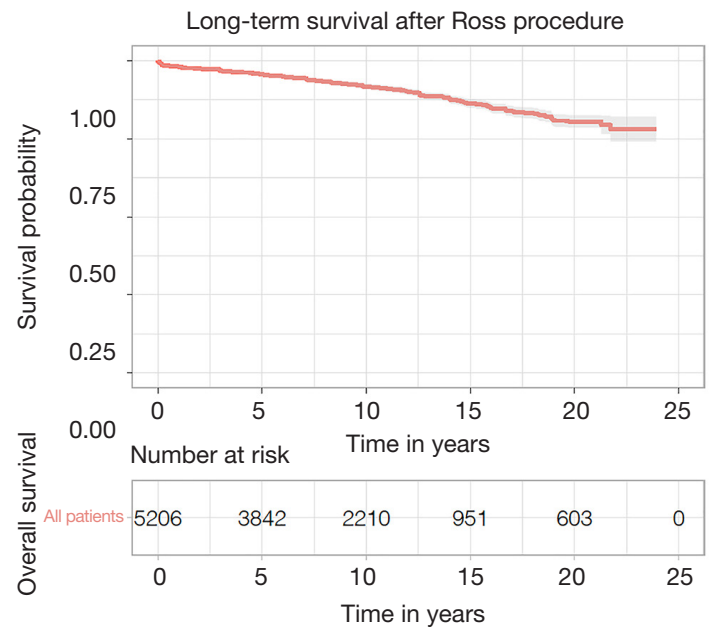

Figure 1 Composite survival curve of overall survival of patients undergoing the Ross procedure.

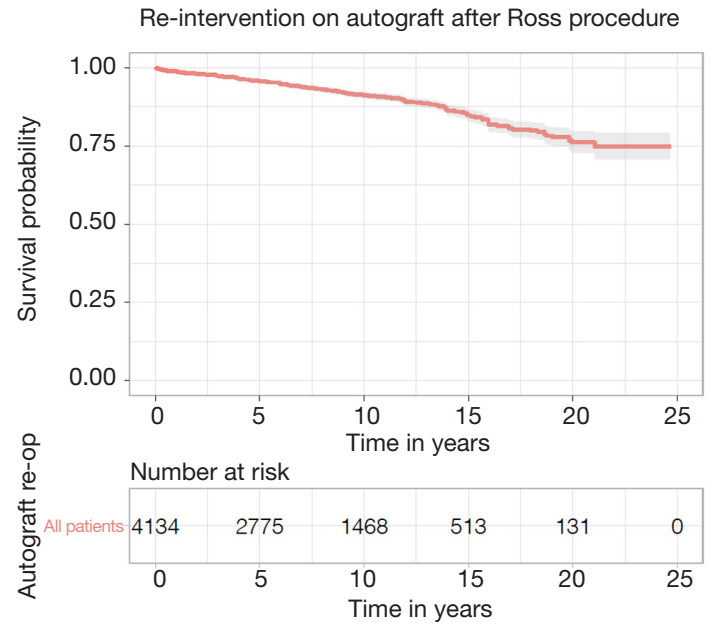

Figure 2 Composite survival curve of overall autograft reoperation rates for adult patients undergoing the Ross procedure.

$(12-15,17,18,20,21,23,24,26,29,30,32)$ with a total patient population of 3,305. Endocarditis occurred in seventyfour patients $(2.24 \%)$ during the entire follow-up period, however, there is insufficient data available to determine the proportion of endocarditis that necessitated reoperation.

\section{Overall survival}

Composite survival analysis was derived from fifteen studies (11,13-19,21-24,26,30,32). Assessment of composite Kaplan-Meier analysis reveals long-term survival after Ross procedure was $95.6 \%$ (95\% CI: 95.0-96.2\%), 91.8\% (95\% CI: 90.9-92.7\%), 86.3\% (95\% CI: 84.9-87.7\%) and 80.5\% (95\% CI: 78.6-82.5\%) at five, ten, fifteen, and twenty years, respectively (Figure 1).

\section{Reintervention on autograft}

Composite survival analysis for re-intervention on the autograft was derived from thirteen studies $(11,12,15,17,21,22,24,26-28,30-32)$. Pooled survival analysis of all methods of implanting the pulmonary autograft revealed that freedom from re-intervention on the aortic valve was $95.7 \%$ (95\% CI: 95.1-96.4\%), 91.2\% (95\% CI: 90.1-92.3\%), 84.9\% (95\% CI: $83.0-86.8 \%$ ) and $76.1 \%$ (95\% CI: 72.8-79.8\%) at five, ten, fifteen, and twenty years, respectively (Figure 2). There is insufficient published data to analyze re-intervention rates for different autograft implantation techniques.

\section{Reintervention on RVOT}

Composite survival analysis for re-intervention on the RVOT was derived from ten studies (10-12,17,18,20$22,26,28)$. On assessment of composite Kaplan-Meier analysis, freedom from intervention (percutaneous or surgical) on the RVOT was 95.0\% (95\% CI: 94.2-95.7\%), 90.6\% (95\% CI: 89.5-91.7\%), 87.8\% (95\% CI: $86.3-$ $89.2 \%)$ and $84.1 \%(81.9-86.3 \%)$ at five, ten, fifteen, and twenty years, respectively (Figure 3).

Two studies presented survival data for freedom from re-intervention on the RVOT that was reconstructed with xenograft $(17,22)$ and eight studies reported survival data for RVOT reconstruction with homograft (10-12,18,20-22,26). Freedom from re-intervention on homograft reconstruction of the RVOT was $97.9 \%$ (95\% CI: $97.4-98.4 \%$ ) and $96.1 \%$ (95\% CI: 95.3-96.9\%), 93.5\% (95\% CI: 92.3-94.8\%) and $89.6 \%$ (95\% CI: 87.4-91.9\%) at five, ten, fifteen, and twenty years, respectively. Freedom from reintervention on xenograft reconstruction of the RVOT was $77.7 \%$ (95\% CI: 71.4-81.4\%) and 61.0\% (95\% CI: 56.0-66.5\%) five and ten years respectively (Figure 4).

\section{Discussion}

The two main concerns regarding the Ross procedure are the increased early peri-operative risks associated with a complicated operation in order to address aortic valve disease and, the durability of the aortic and pulmonary valve 


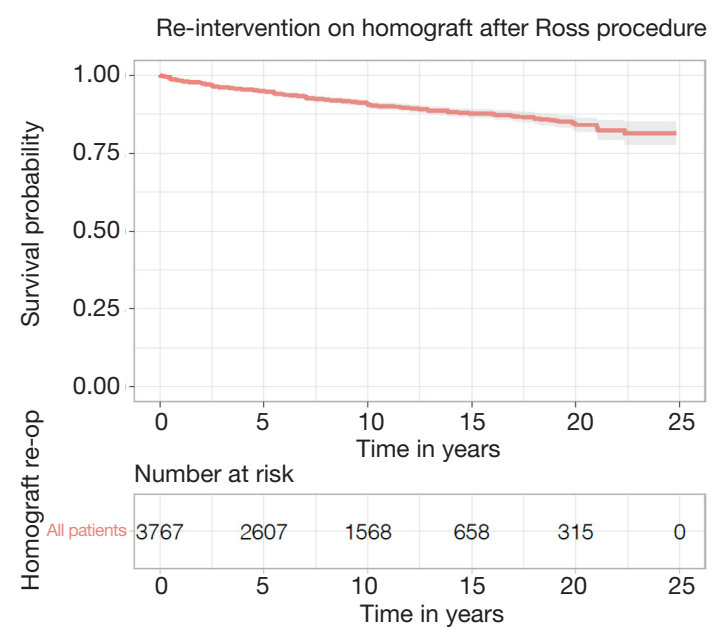

Figure 3 Composite survival curve of homograft re-intervention rates of adult patients undergoing the Ross procedure.

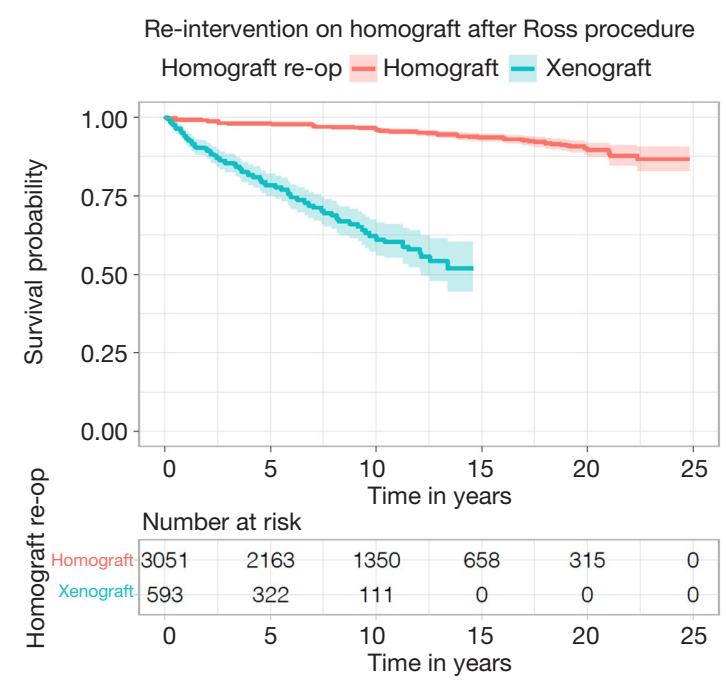

Figure 4 Composite survival curves of right ventricular outflow tract (RVOT) re-intervention in adult patients undergoing the Ross procedure stratified by prosthesis type.

replacement. This study attempts to determine the true risk through thorough enhanced survival analysis, limiting analysis to experienced centers with published long-term data.

The landscape of aortic valve intervention has been consistently evolving over the last few decades for all treatment options, be it mechanical valves that require lower reference international normalized ratios (INRs) with improved transvalvular gradients (33), rapid deployment bioprosthetic valves to reduce implantation times and simplify operative intervention (34-36) and the revolutionary advent of transcatheter valve intervention. Nevertheless, the decision making on the optimal prosthesis for young patients is still far from easy. The Ross procedure is an often forgotten option that may be of benefit for certain population groups.

This meta-analysis of a large number of experienced centers has demonstrated highly durable results from both the aortic and pulmonary components of the operation with excellent freedom from reoperation. The management of the autograft in this study was varied between groups with unfortunately insufficient data available to determine if any difference in freedom from autograft re-intervention exists between the three main techniques. The subcoronary technique was the technique originally defined by Ross in 1967 and is a technically demanding operation that requires close attention be paid to the position of the commissures to ensure perfect valve geometry, otherwise placing the patient at risk of early autograft failure. The majority of patients in this series underwent a full root replacement technique requiring reimplantation of one or both coronary arteries. Frequently, the aortic annulus was supported with a strip of pericardium or Teflon felt to prevent annular dilatation. However, this technique does not provide any reinforcement to the neo-sinus. Leaving the autograft unsupported may risk progressive neo-aortic root dilatation as was seen as a common cause of reoperation in several studies included in this meta-analysis $(12,15,26,32)$. Reinforcing the autograft with prosthetic or autologous tissue is a newer development in the procedure that aims to reduce the risk of mid- and long-term autograft failure by preventing progressive autograft dilatation. With the current data, Sievers et al. (22) did not demonstrate a difference at seventeen years between reinforced root and unsupported root techniques. Furthermore, Mastrobuoni et al. (24) also found no difference in reoperation rates between reinforced and free-standing implantation of the autograft. However, Buratto and colleagues (19) demonstrated very low twenty-year reoperation rates of $9 \%$ overall in a patient population who received a supported technique of autograft re-implantation. This is an interesting area of study with regards to the optimal long-term performance of the autograft in the Ross procedure.

An important finding is that reintervention on the RVOT was markedly increased with the use of xenografts for RVOT reconstruction. Although the data detailing the use of xenografts was derived from only two studies with a shorter follow-up period, the marked reduction in 
performance suggests that xenograft should only be used in exceptional circumstances. The use of homografts to reconstruct the RVOT is durable with exceptionally low long-term reoperation rates as low as $3 \%$ at twenty years, as demonstrated by Fricke and colleagues (37).

The complicated decision of choosing the most appropriate prosthesis for younger patients usually will revolve around the dichotomous decision of mechanical or bioprosthetic valve replacement. Reoperation rates are known to be significantly lower for mechanical prostheses, as compared to bioprosthetic valves with fifteen-year reoperation rates $4-6.9 \%$ for mechanical valves and $12.1 \%$ for bioprosthetic valves $(1,2,38)$. The propensity-matched study comparing the Ross procedure to mechanical aortic valve implantation by Buratto et al. (19) included in this analysis, did not show any significant difference in reoperation rate between mechanical aortic valve with an $8 \%$ reoperation rate and Ross procedure, with reoperation rates at $8 \%$ and $9 \%(\mathrm{P}=0.74)$ at twenty years, respectively. Beyond reoperation rates, the Ross procedure has been associated with significant survival benefits when compared to other valve prostheses, with patients having similar long-term survival as the general population. However, it is important to note that patients undergoing the Ross procedure are highly selected and are therefore less likely to have significant comorbidities which may explain some long-term differences in patient outcomes.

The thrombogenic nature of mechanical aortic valve prostheses necessitates lifelong anticoagulation with the attendant risk of bleeding. The lifelong risk of stroke and bleeding for young patients is significant. Patients with a mechanical aortic valve have an annual risk of major bleed of $0.85-1.4 \%(23,39)$ and an annual risk of stroke of $0.74-1.4 \%(40,41)$. Mazine et al. (23) directly compared the outcomes of Ross procedure with mechanical aortic valve replacement and demonstrated significantly fewer strokes, transient ischemic attacks (TIAs) and significant bleeding events in the Ross procedure group, as compared to the mechanical valve group.

\section{Limitations}

Current data in unique datasets are limited to predominantly single center studies that are retrospective in nature. However, the presence of one large multi-center registry data does represent real world data, however, there was insufficient data to meaningfully extract information regarding different techniques of autograft implantation.
This is an area of interest as the method of autograft failure is frequently, through regurgitation, due to aortic neo-root dilatation.

\section{Conclusions}

When performed in experienced centers and for appropriately selected patients, the Ross procedure represents a durable replacement of the aortic valve with excellent long-term survival and, relatively low rates of re-intervention on the autograft and RVOT homograft. Furthermore, the use of xenograft to repair the RVOT does not appear to be a durable substitute and should be avoided where possible.

\section{Acknowledgments}

Funding: None.

\section{Footnote}

Conflicts of Interest: The authors have no conflicts of interest to declare.

Open Access Statement: This is an Open Access article distributed in accordance with the Creative Commons Attribution-NonCommercial-NoDerivs 4.0 International License (CC BY-NC-ND 4.0), which permits the noncommercial replication and distribution of the article with the strict proviso that no changes or edits are made and the original work is properly cited (including links to both the formal publication through the relevant DOI and the license). See: https://creativecommons.org/licenses/by-nc-nd/4.0/.

\section{References}

1. Chiang YP, Chikwe J, Moskowitz AJ, et al. Survival and long-term outcomes following bioprosthetic vs mechanical aortic valve replacement in patients aged 50 to 69 years. JAMA 2014;312:1323-9.

2. Ruel M, Kulik A, Lam BK, et al. Long-term outcomes of valve replacement with modern prostheses in young adults. Eur J Cardiothorac Surg 2005;27:425-33; discussion 433.

3. Ross DN. Replacement of aortic and mitral valves with a pulmonary autograft. Lancet 1967;2:956-8.

4. Bouhout I, Ghoneim A, Poirier N, et al. Impact of the Learning Curve on Early Outcomes Following the Ross Procedure. Can J Cardiol 2017;33:493-500. 
5. Stelzer P, Itagaki S, Varghese R, et al. Operative mortality and morbidity after the Ross procedure: a 26- year learning curve. J Heart Valve Dis 2013;22:767-75.

6. Wan X, Wang W, Liu J, et al. Estimating the sample mean and standard deviation from the sample size, median, range and/or interquartile range. BMC Med Res Methodol 2014;14:135.

7. Guyot P, Ades AE, Ouwens MJ, et al. Enhanced secondary analysis of survival data: reconstructing the data from published Kaplan-Meier survival curves. BMC Med Res Methodol 2012;12:9.

8. Saluja R, Cheng S, Delos Santos KA, et al. Estimating hazard ratios from published Kaplan-Meier survival curves: A methods validation study. Res Synth Methods 2019;10:465-75.

9. Institute of Health Economics. Quality Appraisal of Case Series Studies Checklist. Edmonton (AB): Institute of Health Economics, 2014.

10. Oeser C, Uyanik-Uenal K, Kocher A, et al. Long-term performance of pulmonary homografts after the Ross procedure: experience up to 25 years. Eur J Cardiothorac Surg 2019;5 5:876-84.

11. Bansal N, Kumar SR, Baker CJ, et al. Age-Related Outcomes of the Ross Procedure Over 20 Years. Ann Thorac Surg 2015;99:2077-83; discussion 2084-5.

12. Pergola V, Di Salvo G, Fadel B, et al. The long term results of the Ross procedure: The importance of candidate selection. Int J Cardiol 2020;320:35-41.

13. Loobuyck V, Soquet J, Moussa MD, et al. Active Aortic Endocarditis in Young Adults: Long-term Results of the Ross Procedure. Ann Thorac Surg 2020;110:856-61.

14. Chauvette V, Bouhout I, Lefebvre L, et al. The Ross procedure is a safe and durable option in adults with infective endocarditis: a multicentre study. Eur J Cardiothorac Surg 2020;58:537-43.

15. Sharifulin R, Bogachev-Prokophiev A, Zheleznev S, et al. Factors impacting long-term pulmonary autograft durability after the Ross procedure. J Thorac Cardiovasc Surg 2019;157:134-141.e3.

16. Guerreiro S, Madeira M, Ribeiras R, et al. Long-term assessment of the Ross procedure in adults: Clinical and echocardiographic follow-up at 20 years. Rev Port Cardiol (Engl Ed) 2019;38:315-21.

17. Christ T, Paun AC, Grubitzsch H, et al. Long-term results after the Ross procedure with the decellularized AutoTissue Matrix $\mathrm{P} \circledast$ bioprosthesis used for pulmonary valve replacement. Eur J Cardiothorac Surg 2019;55:885-92.

18. Etnel JRG, Suss PH, Schnorr GM, et al. Fresh decellularized versus standard cryopreserved pulmonary allografts for right ventricular outflow tract reconstruction during the Ross procedure: a propensity-matched study. Eur J Cardiothorac Surg 2018;54:434-40.

19. Buratto E, Shi WY, Wynne R, et al. Improved Survival After the Ross Procedure Compared With Mechanical Aortic Valve Replacement. J Am Coll Cardiol 2018;71:1337-44.

20. Pardo González L, Ruiz Ortiz M, Delgado M, et al. Pulmonary homograft stenosis in the Ross procedure: Incidence, clinical impact and predictors in long-term follow-up. Arch Cardiovasc Dis 2017;110:214-22.

21. Martin E, Mohammadi S, Jacques F, et al. Clinical Outcomes Following the Ross Procedure in Adults: A 25-Year Longitudinal Study. J Am Coll Cardiol 2017;70:1890-9.

22. Sievers HH, Stierle U, Charitos EI, et al. A multicentre evaluation of the autograft procedure for young patients undergoing aortic valve replacement: update on the German Ross Registry†. Eur J Cardiothorac Surg 2016;49:212-8.

23. Mazine A, David TE, Rao V, et al. Long-Term Outcomes of the Ross Procedure Versus Mechanical Aortic Valve Replacement: Propensity-Matched Cohort Study. Circulation 2016;134:576-85.

24. Mastrobuoni S, de Kerchove L, Solari S, et al. The Ross procedure in young adults: over 20 years of experience in our Institution. Eur J Cardiothorac Surg 2016;49:507-12; discussion 512-3.

25. Juthier F, Vincentelli A, Hysi I, et al. Stentless porcine bioprosthesis in pulmonary position after ross procedure: midterm results. Ann Thorac Surg 2015;99:1255-9.

26. Escarain MC, Giunta G, Favaloro RR. Ross procedure in adults: is reoperation a real concern? J Heart Valve Dis 2015;24:247-52.

27. Ryan WH, Prince SL, Culica D, et al. The Ross procedure performed for aortic insufficiency is associated with increased autograft reoperation. Ann Thorac Surg 2011;91:64-9; discussion 69-70.

28. Brown JW, Ruzmetov M, Shahriari A, et al. The Ross full root replacement in adults with bicuspid aortic valve disease. J Heart Valve Dis 2011;20:332-9; discussion 340.

29. Aljassim O, Svensson G, Perrotta S, et al. Dilatation of the pulmonary autograft and native aorta after the Ross procedure: a comprehensive echocardiographic study. J Thorac Cardiovasc Surg 2011;142:634-40, 640.e1.

30. El-Hamamsy I, Eryigit Z, Stevens LM, et al. Longterm outcomes after autograft versus homograft aortic 
root replacement in adults with aortic valve disease: a randomised controlled trial. Lancet 2010;376:524-31.

31. Frigiola A, Ranucci M, Carlucci C, et al. The Ross procedure in adults: long-term follow-up and echocardiographic changes leading to pulmonary autograft reoperation. Ann Thorac Surg 2008;86:482-9.

32. Settepani F, Kaya A, Morshuis WJ, et al. The Ross operation: an evaluation of a single institution's experience. Ann Thorac Surg 2005;79:499-504.

33. Yanagawa B, Levitsky S, Puskas JD, et al. Reduced anticoagulation is safe in high-risk patients with the On-X mechanical aortic valve. Curr Opin Cardiol 2015;30:140-5.

34. Bening C, Hamouda K, Oezkur M, et al. Rapid deployment valve system shortens operative times for aortic valve replacement through right anterior minithoracotomy. J Cardiothorac Surg 2017;12:27.

35. Ferrari E, Roduit C, Salamin P, et al. Rapid-deployment aortic valve replacement versus standard bioprosthesis implantation. J Card Surg 2017;32:322-7.

36. Schlömicher M, Bechtel M, Taghiyev Z, et al.

Cite this article as: Flynn CD, De Bono JH, Muston B, Rattan N, Tian DH, Larobina M, O'Keefe M, Skillington P. Systematic review and meta-analysis of long-term outcomes in adults undergoing the Ross procedure. Ann Cardiothorac Surg 2021;10(4):411-419. doi: 10.21037/acs-2021-rp-30
Intermediate Outcomes after Rapid Deployment Aortic Valve Replacement in Multiple Valve Surgery. Thorac Cardiovasc Surg 2020;68:595-601.

37. Fricke TA, Skillington PD, Shi WY, et al. Pulmonary Valve Function Late After Ross Procedure in 443 Adult Patients. Ann Thorac Surg 2020;109:1127-31.

38. Kytö V, Sipilä J, Ahtela E, et al. Mechanical Versus Biologic Prostheses for Surgical Aortic Valve Replacement in Patients Aged 50 to 70. Ann Thorac Surg 2020;110:102-10.

39. Korteland NM, Etnel JRG, Arabkhani B, et al. Mechanical aortic valve replacement in non-elderly adults: metaanalysis and microsimulation. Eur Heart J 2017;38:3370-7.

40. Badhwar V, Ofenloch JC, Rovin JD, et al. Noninferiority of closely monitored mechanical valves to bioprostheses overshadowed by early mortality benefit in younger patients. Ann Thorac Surg 2012;93:748-53.

41. Ruel M, Masters RG, Rubens FD, et al. Late incidence and determinants of stroke after aortic and mitral valve replacement. Ann Thorac Surg 2004;78:77-83; discussion 83-4. 


\section{Supplementary}

Table S1 Canadian Institute of Health Economics quality appraisal checklist (modified)

\begin{tabular}{|c|c|}
\hline Domain & Description \\
\hline 1 & Was the hypothesis/aim/objective of the study clearly stated (e.g., PICO)? \\
\hline 2 & Was the study concluded prospectively (stated as such)? \\
\hline 3 & Were the cases collected in more than one centre? \\
\hline 4 & Were patients recruited consecutively? \\
\hline 6 & Were the eligibility criteria (i.e., inclusion ad exclusion criteria) for entry in the study clearly stated? \\
\hline 7 & Did patients enter the study at a similar point in the disease? \\
\hline 8 & Was the intervention of interest clearly described? \\
\hline 9 & Were additional interventions (co-interventions) clearly described? \\
\hline 12 & Were the relevant outcome measures made before and after the intervention? \\
\hline 13 & Were the statistical tests used to assess the relevant outcomes appropriate? \\
\hline 14 & Was follow-up long enough for important events and outcomes to occur? \\
\hline 15 & Were losses to follow-up reported? \\
\hline 16 & Did the study provided estimates of random variability in the data analysis of relevant outcomes? \\
\hline 17 & Were the adverse events reported? \\
\hline 18 & Were the conclusions of the study supported by results? \\
\hline 19 & Were conflicts of interest reported? \\
\hline
\end{tabular}


Table S2 Individual study quality assessment based on the Canadian Institute of Health Economics Quality Appraisal Checklist

\begin{tabular}{|c|c|c|c|c|c|c|c|c|c|c|c|c|c|c|c|c|c|c|}
\hline \multirow{2}{*}{ Author, year } & \multirow{2}{*}{ Title } & \multicolumn{15}{|c|}{ Domain number from Canadian Institute of Health Economics Quality Appraisal Checklist } & \multirow{2}{*}{\multicolumn{2}{|c|}{ Total }} \\
\hline & & 1 & 2 & 3 & 4 & 5 & 6 & 7 & 8 & 9 & 10 & 11 & 12 & 13 & 14 & 15 & & \\
\hline Aljassim, 2011 & $\begin{array}{l}\text { Dilatation of the pulmonary autograft and native aorta after the Ross procedure: a } \\
\text { comprehensive echocardiographic study }\end{array}$ & 1 & 0 & 0 & 0 & 1 & 0 & 1 & 1 & 0 & 0 & 1 & 1 & 1 & 0 & 0 & $\bullet$ & 7 \\
\hline Bansal, 2015 & Age-Related Outcomes of the Ross Procedure Over 20 Years & 1 & 0 & 0 & 1 & 1 & 0 & 1 & 1 & 1 & 0 & 0 & 1 & 1 & 1 & 0 & $\bullet$ & 9 \\
\hline Brown, 2011 & The Ross full root replacement in adults with bicuspid aortic valve disease & 1 & 0 & 1 & 1 & 1 & 1 & 1 & 1 & 1 & 0 & 0 & 1 & 1 & 1 & 0 & 0 & 11 \\
\hline Buratto, 2018 & $\begin{array}{l}\text { Improved Survival After the Ross Procedure Compared with Mechanical Aortic Valve } \\
\text { Replacement }\end{array}$ & 1 & 0 & 1 & 0 & 1 & 1 & 1 & 1 & 1 & 1 & 0 & 1 & 1 & 1 & 0 & 0 & 11 \\
\hline Chauvette, 2020 & $\begin{array}{l}\text { The Ross procedure is a safe and durable option in adults with infective endocarditis: a } \\
\text { multicentre study }\end{array}$ & 1 & 1 & 1 & 1 & 1 & 0 & 1 & 1 & 1 & 0 & 1 & 1 & 1 & 1 & 1 & $\circ$ & 13 \\
\hline Christ, 2019 & $\begin{array}{l}\text { Long-term results after the Ross procedure with the decellularized AutoTissue Matrix } \mathrm{P} \\
\mathrm{R} \text { bioprosthesis used for pulmonary valve replacement }\end{array}$ & 1 & 1 & 0 & 0 & 1 & 0 & 1 & 1 & 1 & 1 & 1 & 1 & 1 & 1 & 1 & ○ & 12 \\
\hline El-Hamamsy, 2010 & $\begin{array}{l}\text { Long-term outcomes after autograft versus homograft aortic root replacement in adults } \\
\text { with aortic valve disease: a randomised controlled trial }\end{array}$ & 1 & 1 & 0 & 0 & 1 & 1 & 1 & 1 & 1 & 1 & 1 & 1 & 1 & 1 & 1 & ○ & 13 \\
\hline Escarain, 2015 & Ross procedure in adults: is reoperation a real concern? & 1 & 0 & 0 & 1 & 1 & 0 & 1 & 1 & 1 & 0 & 1 & 1 & 1 & 1 & 0 & ○ & 10 \\
\hline Etnel, 2018 & $\begin{array}{l}\text { Fresh decellularized versus standard cryopreserved pulmonary allografts for right } \\
\text { ventricular outflow tract reconstruction during the Ross procedure: A propensity- } \\
\text { matched study }\end{array}$ & 1 & 0 & 0 & 1 & 1 & 1 & 1 & 1 & 0 & 0 & 0 & 1 & 1 & 1 & 1 & 0 & 10 \\
\hline Frigiola, 2008 & $\begin{array}{l}\text { The Ross procedure in adults: long-term follow-up and echocardiographic changes } \\
\text { leading to pulmonary autograft reoperation }\end{array}$ & 1 & 0 & 0 & 0 & 1 & 1 & 1 & 1 & 0 & 0 & 0 & 1 & 1 & 1 & 0 & $\bullet$ & 8 \\
\hline Guerreiro, 2019 & $\begin{array}{l}\text { Long-term assessment of the Ross procedure in adults: Clinical and echocardiographic } \\
\text { follow-up at } 20 \text { years }\end{array}$ & 1 & 0 & 0 & 1 & 1 & 1 & 1 & 1 & 1 & 1 & 1 & 0 & 1 & 1 & 1 & 0 & 12 \\
\hline Juthier, 2015 & $\begin{array}{l}\text { Stentless porcine bioprosthesis in pulmonary position after ross procedure: midterm } \\
\text { results }\end{array}$ & 1 & 0 & 0 & 1 & 1 & 1 & 0 & 1 & 1 & 0 & 0 & 1 & 1 & 0 & 0 & $\bullet$ & 8 \\
\hline Loobuyck, 2020 & Active aortic endocarditis in young adults: long-term results of the Ross procedure & 1 & 0 & 0 & 0 & 1 & 0 & 1 & 1 & 1 & 0 & 1 & 1 & 1 & 1 & 0 & $\bullet$ & 9 \\
\hline Martin, 2017 & Clinical Outcomes Following the Ross Procedure in Adults: A 25-Year Longitudinal Study & 1 & 1 & 0 & 0 & 1 & 1 & 1 & 1 & 1 & 0 & 1 & 1 & 1 & 1 & 0 & ○ & 11 \\
\hline Mastrobuoni, 2016 & The Ross procedure in young adults: over 20 years of experience in our Institution & 1 & 0 & 1 & 0 & 1 & 1 & 1 & 1 & 1 & 1 & 1 & 1 & 1 & 1 & 1 & ○ & 13 \\
\hline Mazine, 2016 & $\begin{array}{l}\text { Long-Term Outcomes of the Ross Procedure Versus Mechanical Aortic Valve } \\
\text { Replacement: Propensity-Matched Cohort Study }\end{array}$ & 1 & 0 & 0 & 0 & 1 & 1 & 1 & 1 & 1 & 1 & 1 & 1 & 1 & 1 & 1 & 0 & 12 \\
\hline Oeser, 2019 & $\begin{array}{l}\text { Long-term performance of pulmonary homografts after the Ross procedure: experience } \\
\text { up to } 25 \text { years }\end{array}$ & 1 & 0 & 0 & 1 & 1 & 1 & 1 & 1 & 1 & 0 & 1 & 1 & 1 & 1 & 1 & 0 & 12 \\
\hline Pardo Gonzalez, 2017 & $\begin{array}{l}\text { Pulmonary homograft stenosis in the Ross procedure: Incidence, clinical impact and } \\
\text { predictors in long-term follow-up }\end{array}$ & 1 & 1 & 0 & 1 & 1 & 0 & 1 & 1 & 0 & 1 & 1 & 1 & 1 & 1 & 1 & 0 & 12 \\
\hline Pergola, 2020 & The long term results of the Ross procedure: The importance of candidate selection & 1 & 0 & 0 & 0 & 1 & 0 & 1 & 1 & 1 & 1 & 1 & 1 & 1 & 1 & 0 & 0 & 10 \\
\hline Ryan, 2011 & $\begin{array}{l}\text { The Ross procedure performed for aortic insufficiency is associated with increased } \\
\text { autograft reoperation }\end{array}$ & 1 & 1 & 0 & 1 & 0 & 1 & 1 & 1 & 0 & 0 & 1 & 1 & 1 & 1 & 0 & ○ & 10 \\
\hline Settepani, 2005 & The Ross operation: an evaluation of a single institution's experience & 1 & 0 & 0 & 0 & 1 & 0 & 1 & 1 & 1 & 0 & 1 & 1 & 1 & 1 & 0 & $\bullet$ & 9 \\
\hline Sharifulin, 2019 & Factors impacting long-term pulmonary autograft durability after the Ross procedure & 1 & 0 & 0 & 1 & 1 & 1 & 1 & 1 & 1 & 1 & 1 & 1 & 1 & 1 & 1 & ○ & 13 \\
\hline Sievers, 2016 & $\begin{array}{l}\text { A multicentre evaluation of the autograft procedure for young patients undergoing aortic } \\
\text { valve replacement: update on the German Ross Registry }\end{array}$ & 1 & 1 & 1 & 0 & 1 & 0 & 0 & 0 & 1 & 1 & 1 & 1 & 1 & 1 & 1 & 0 & 11 \\
\hline
\end{tabular}

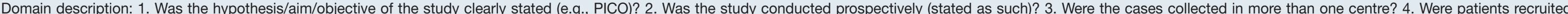

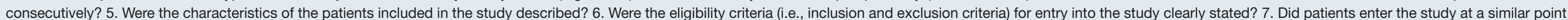

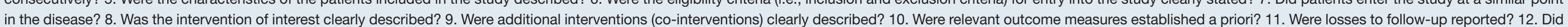

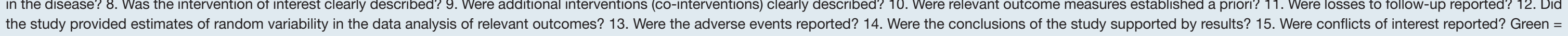
high quality, yellow $=$ moderate quality, red $=$ low quality. 


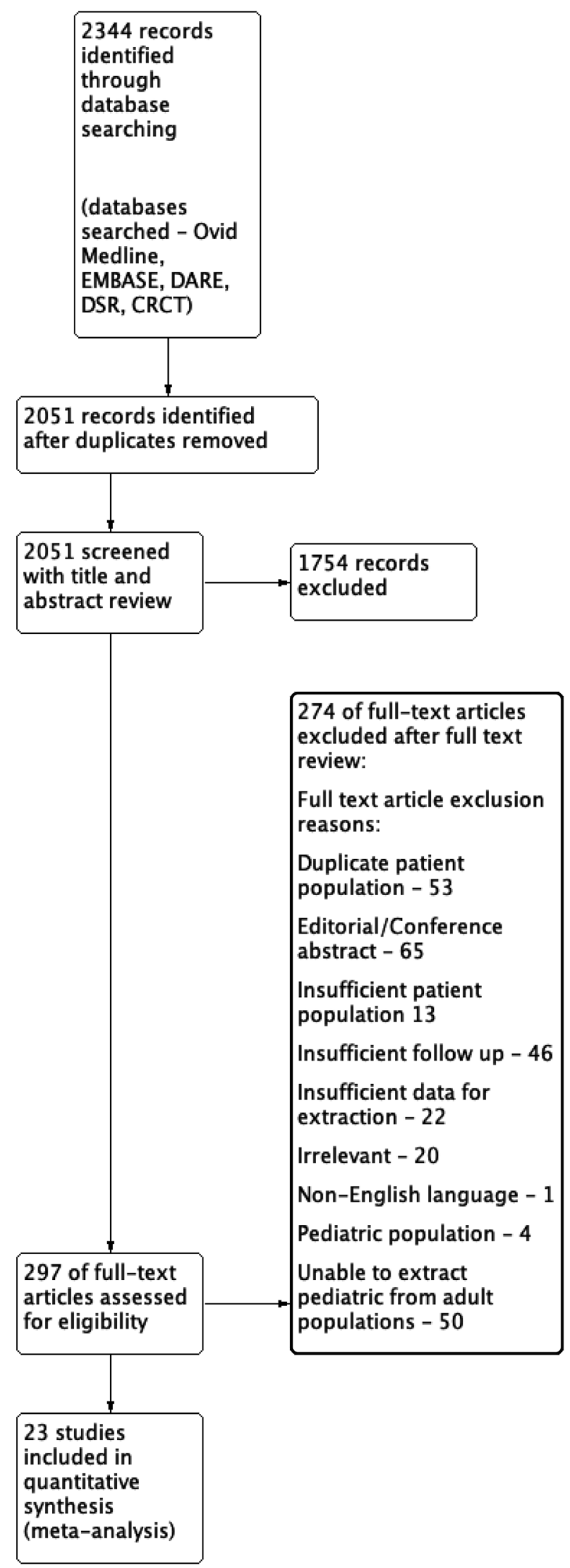

Figure S1 PRISMA diagram detailing meta-analysis strategy for the analysis of the Ross procedure in adult patients. 